\title{
Enlightenment of IKEA’s Multinational Operations to Chinese Enterprises
}

\author{
—From the Aspect of International Tax Planning \\ Qingqing Wu*, Jie Peng \\ School of Nanjing University of Science and Technology, Nanjing 210000, China \\ 2456142051@qq.com
}

Keywords: IKEA; International Tax Planning; Transnational Operation; Anti-tax avoidance;

\begin{abstract}
In the exploration of operating internationally for Chinese enterprises, it's remarkable to find how to maximize their comprehensive income better through the international tax planning. This paper analyzes the IKEA group's company structure and tax policy, then it shows three revelations for Chinese enterprises in transnational operation to seek more favorable tax status.
\end{abstract}

\section{Introduction}

International tax planning refers to multinational corporations complying with the tax laws of various countries and international tax treaties during the course of business operations, and make reasonable arrangements for taxable activities such as investment and operations, so as to minimize the overall tax burden of multinational corporations and maximize the company's own comprehensive income. In recent years, driven by the tide of economic globalization and the policy of "the Belt and Road", China's foreign investment has been increasing significantly. More and more local companies have gone abroad to seek cheaper production costs, more advanced technologies and management and wider overseas markets. It have become more active and involved in global competition. Therefore, it is worth paying attention to how to realize the maximization of the company's own comprehensive income through international tax planning.

Ingvar Kamprad founded IKEA in Småland, Sweden in 1943 and opened his first retail store in 1958. Today, IKEA, as the public sees it, is a globally renowned multinational company, with a giant enterprise of €34.1 billion in annual sales, 149,000 employees, and at least 355 stores in more than 29 countries by 2017. IKEA's complex corporate structure (fund+trust fund+joint-stock company) and a series of tax avoidance means enable it to achieve the goal of maximizing tax benefits. In February, 2016, The Greens released a report that IKEA has used Dutch tax conduits, in-house loan facilities and tax havens to avoid paying about 1 billion euros from 1991 to 2004. So, this paper hopes to study the company structure and tax avoidance strategy of IKEA expected to bring enlightenment for Chinese enterprises in the "going global" strategy to obtain more favorable tax status in the complex international competitive environment.

\section{The corporate structure of the IKEA}

As shown in fig 1, at the top of IKEA's corporate structure is the IKANO Group, a Netherlands private fund controlled by the Kamprad family and a small Group of partners, which is exempt under Netherlands law. The second layer of the company's structure is the two trust funds controlled by the IKANO Group: the Interogo Foundation, established in 1989 in Liechtenstein, and the Stichting INGKA Foundation in the Netherlands. The third layer of the company's structure is the Inter IKEA Group and IKEA Group, two separate conglomerates controlled by two trust funds. The Interogo fundation controls the Inter IKEA Group by owning Inter IKEA Holding SA, a luxembourg-based holding company. Stichting INGKA controls IKEA Group by owning INGKA Holding BV, a Netherlands Holding company. Functionally, the two corporate groups play complementary roles and there does not seem to be any substantive operational rationale for their separation. However, dividing IKEA into two corporate groups may help to facilitate, or at least 
mask, large-scale profit-shifting.

The Inter IKEA Group owns the IKEA “retail system” and, the IKEA trademark before 2012. After 2012, the ownership of the IKEA trademark was sold to the group's plate for the purpose of tax avoidance, a newly established Netherlands subsidiary Inter IKEA Systems BV . This Group is the franchisor of IKEA and every IKEA store in the world sends Inter IKEA royalties equal to 3\% of sales. As detailed below, these royalty payments are a powerful tool for shifting profits and avoiding taxes. The Inter IKEA Group also operates financial and real estate businesses with activities that are sometimes, but not always, related to IKEA.

The IKEA Group operates 355 IKEA stores in 29 countries under franchise agreements with the Inter IKEA Group. In addition, the Group currently owns IKEA's factories, forestry operations and logistics network as well as subsidiaries responsible for developing the IKEA product range.

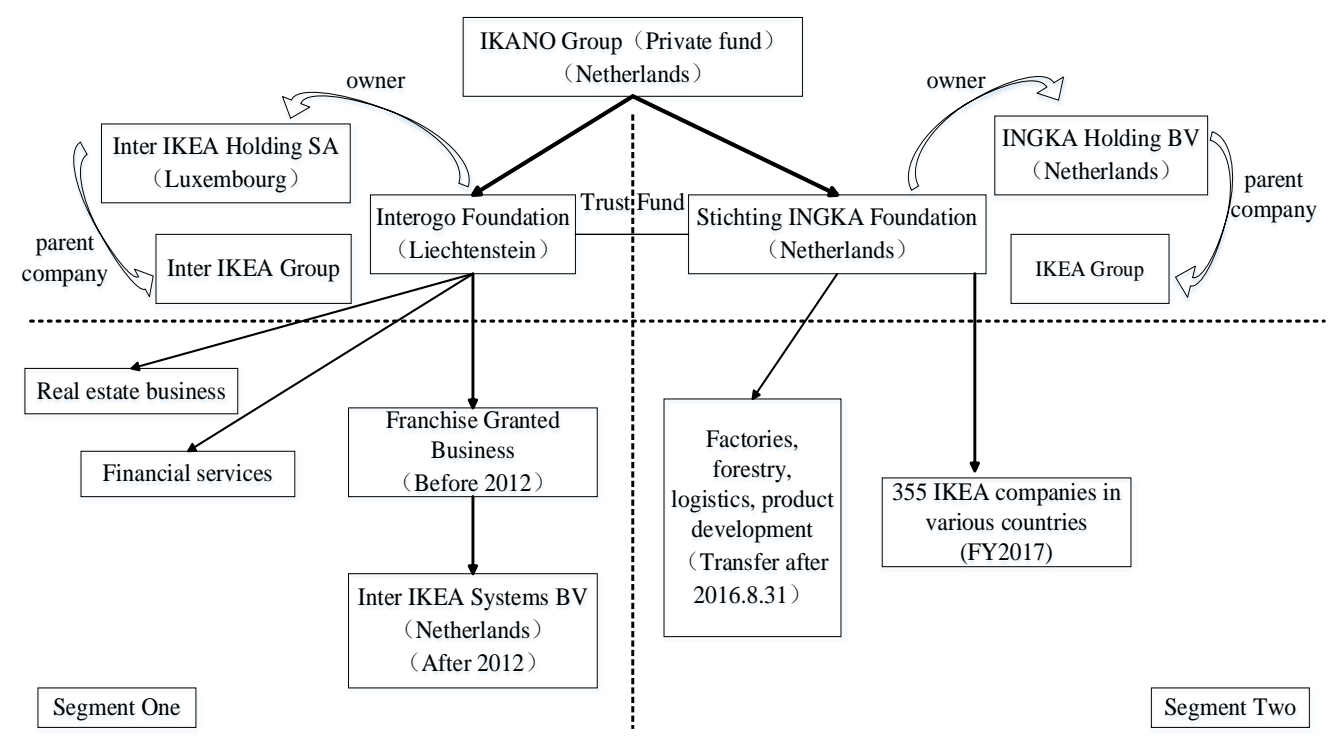

Fig. 1 The corporate structure of the IKEA

\section{Tax Avoidance Strategies and Effects of IKEA}

\subsection{Tax avoidance strategies and effects on royalties}

\subsubsection{Set up a subsidiary in the Netherlands (Inter IKEA Systems BV)}

The Netherlands has long been a popular jurisdiction for the establishment of so-called "royalty conduit" companies because of the opportunity to benefit from the combined effects of Dutch tax law, the country's wide network of tax treaties and its EU membership: First, The Netherlands has a wide network of double tax treaties which eliminate or minimize the possibility for the source country to tax royalties and interest payments sent to the Netherlands. Then, the Netherlands does not impose withholding tax on royalties and interest payments sent abroad, even when the destination is a tax haven. Third, The Dutch "Innovation Box" regime in effect since 2007 taxes royalty income at a preferential tax rate of $5 \%$, as compared with the statutory corporate income tax of $25 \%$. At last, Dutch companies are covered by the EU parent-subsidiary directive, which effectively eliminates withholding taxes on payments between parents and subsidiaries within the EU.

\subsubsection{Move royalties from the Netherlands to Liechtenstein to remain untaxed}

IKEA Group subsidiaries move a large part of their income to Inter IKEA Systems BV in the Netherlands. Subsequently the Inter IKEA Group makes sure much of this income remains untaxed by transferring it (directly or indirectly) to other entities, including the Liechtenstein-domiciled Interogo Foundation. It is doing so partly by using payments of interest on intracompany debt via a subsidiary in Luxembourg.

Since the Interogo Foundation (Liechtenstein) sold the IKEA trademark to the Inter IKEA 
Systems BV in the Netherlands for $€ 9$ billion on January 1, 2012, the Inter IKEA Group used two different Introduction of royalty transfer income transfer plan.

1) Inter IKEA Group's franchise fee income transfer plan before 2012

The annual accounts filed by Inter IKEA Holding SA (the parent company of the Inter IKEA Group in Luxembourg) reveal that, in every year since 1991, the Inter IKEA Group has incurred a large expense item designated only as “other charges.” From 1991 through 2011, these expenses totalled $€ 10.5$ billion - equal to $95 \%$ of the income generated by franchise and license fees during that same period (€11.1 billion). At the level of the Inter IKEA Group as a whole, then, these unspecified "other charges" seem to be sufficient to almost entirely offset the royalty income received from IKEA stores. In other words, Inter IKEA Group pays "other fees” to Interogo Foundation to achieve the purpose of transferring royalties to taxation paradise.

The Inter IKEA Group's royalty income transfer plan before 2012 is shown in Fig. 2.

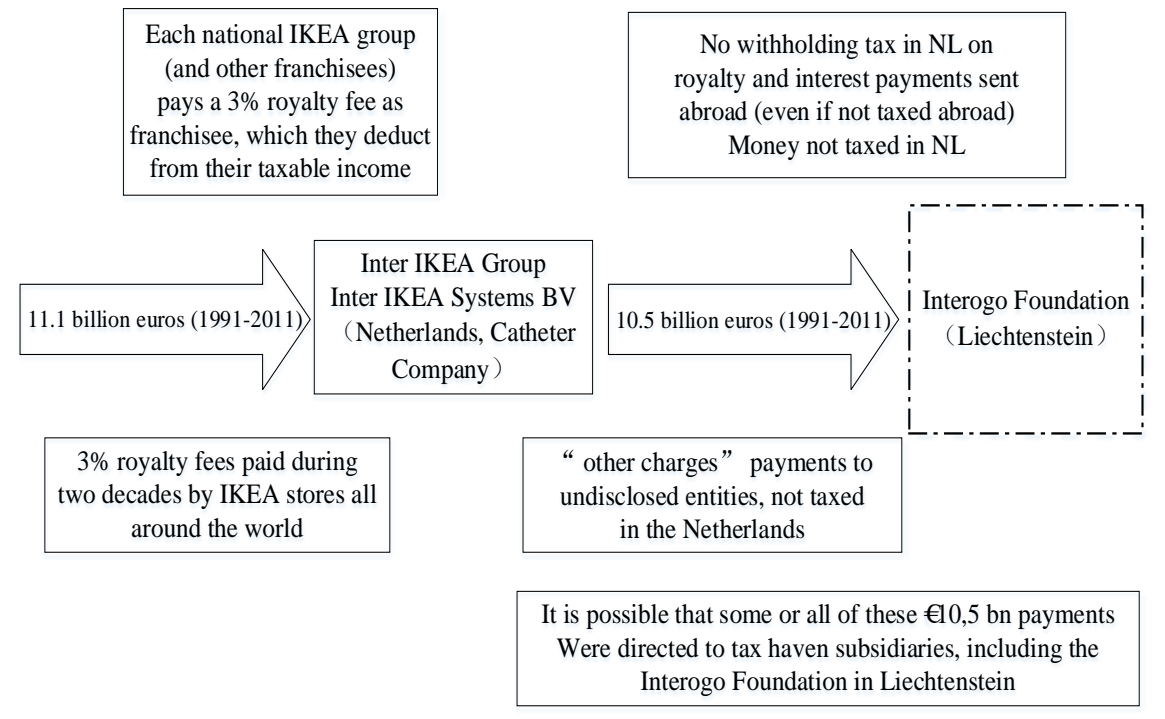

Fig. 2 Inter IKEA Group profit shifting scheme through 2011

2) Inter IKEA Group's profit transfer plan after 2012

Effective 1 January 2012, the Interogo Foundation (in Liechtenstein) sold the IKEA trademark to Inter IKEA Systems BV (in the Netherlands) for $€ 9$ billion. This " $€ 9$ billion coup" was financed with $€ 5.4$ billion in loans from Interogo to Inter IKEA Systems BV and a €3.6 billion share premium issued to Interogo. This transaction therefore created a debt of several billions for Inter IKEA Systems BV (in the Netherlands) simply by transferring legal ownership of the IKEA brand (previously owned by Interogo in Liechtenstein).

Of course, this new "debt" was essentially manufactured out of thin air by the sale of the previously unvalued trademark. This debt now allows the Inter IKEA Group to shift profits to its legal owner (Interogo Foundation) through tax-deductible interest payments. In fact, from 2012 to 2014, Inter IKEA Systems BV in the Netherlands paid €972 million in tax-deductible interest to Interogo Finance SA in Luxembourg, a subsidiary of the Interogo Foundation (in Liechtenstein). Interogo Finance SA paid tax in Luxembourg at just $0.06 \%$ over the three-year period, while sending €807.8 million in dividends to the Interogo Foundation in Liechtenstein. In addition, the Inter IKEA Group has continued, like before 2012, to incur expenses characterized only as "other charges” for a total amount of $€ 587$ million over 2012- 2014. As previously discussed, the recipient of these payments is undisclosed, but they could be used to shift royalty income.

Inter IKEA Group profit shifting scheme since 2012 is shown in Fig. 3. 


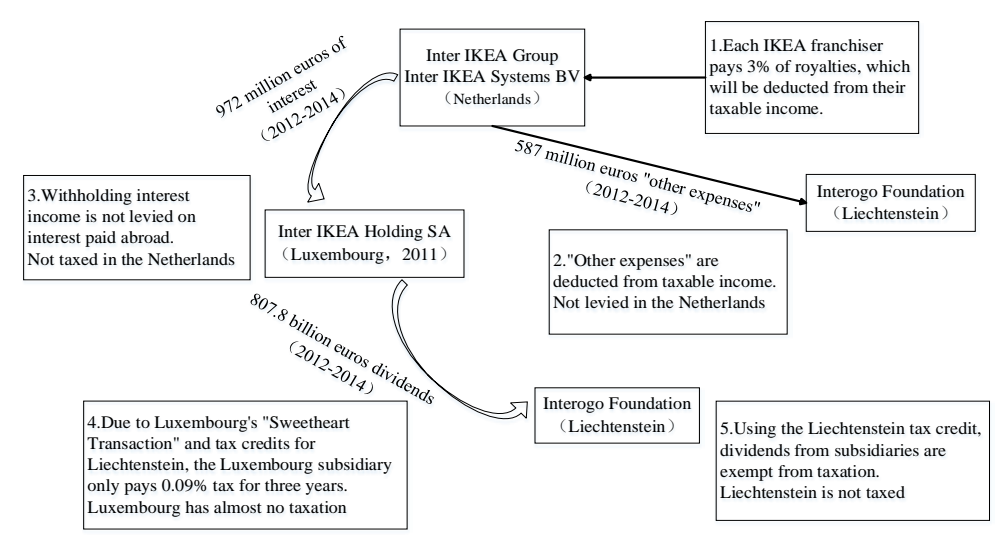

Fig. 3 Inter IKEA Group profit shifting scheme since 2012

\subsubsection{Effect - send billions in tax-deductible royalties to Dutch subsidiary}

From 1991 to 2014, IKEA franchisees paid €13.6 billion in tax-deductible royalties to the Inter IKEA Group. Today, they pay Inter IKEA more than $€ 1$ billion annually. On a worldwide basis, royalty payments from 2009 through 2014 equalled $€ 6.1$ billion - an estimated 22.7\% of net income. Its tax effect is shown in Table 1.

Table 1 Estimated impact of royalties on taxable income of all IKEA franchisees worldwide (not just the IKEA Group), 2009-2014 Unit: 1 billion euro

\begin{tabular}{l|c|c|c|c|c|c|c}
\hline & 2014 & 2013 & 2012 & 2011 & 2010 & 2009 & Cumulati \\
\hline Estimated net profit for all & 3.8 & 3.8 & 3.7 & 3.4 & 3.1 & 2.9 & 20.7 \\
\hline Franchise and licensing & 1.1 & 1.0 & 1.1 & 1.0 & 1.0 & 0.9 & 6.1 \\
\hline Estimated Impact on & $-22 \%$ & $-22 \%$ & $-22 \%$ & $-23 \%$ & $-24 \%$ & $-24 \%$ & $-22 \%$ \\
\hline
\end{tabular}

Narrowing the focus to IKEA Group subsidiaries and breaking down these data on a per country basis, we end up with impressive figures for tax avoided by just one multinational company in 2014: more than $€ 35$ million in Germany, almost $€ 24$ million in France and $€ 11.6$ million in the UK. For the eight European countries analysed, it is estimated that franchise and license fees reduced taxable income between 35\% (Belgium) and 64\% (France).

\subsection{From Belgium to Luxembourg: Use tax loopholes}

Unfortunately, the Netherlands is not the only EU member that has facilitated aggressive tax planning by IKEA. The Inter IKEA and IKEA groups have also used two other European tax havens - Belgium and Luxembourg - for tax avoidance operations.

\subsubsection{Take advantage of Belgium's coordination center to avoid tax}

Prior to 2010, a Belgian company called Inter IKEA Treasury SA acted as an internal financing arm for the Inter IKEA Group, generating income from interest on loans offered to group companies and paying out interest to unspecified Inter IKEA affiliates from whom it borrowed the money in the first place. Inter IKEA Treasury was formally designated as a "Coordination Centre" -- which entitled it to special tax breaks in Belgium. In 2009, the debt flowing though Inter IKEA Treasury SA amounted to $€ 1.2$ billion and the company paid just $1.98 \%$ tax on $€ 4.7$ million in reported profits.

\subsubsection{Use Notional Interest Deduction in Belgium for tax avoidance}

In February 2003, the European Commission decided that this special tax break constituted illegal state aid, contrary to European law. The EC ordered Belgium to discontinue the scheme, closing it immediately to new entrants and phasing it out with respect to existing beneficiaries not later than 31 December 2010.

To compensate for the demise of the coordination centre regime, Belgium instituted the Notional 
Interest Deduction (NID) in 2007. The NID allows companies to deduct fictional interest payments from their taxable income. In practice, the NID can be combined with other elements of Belgian tax law to achieve similar results to the coordination centre regime - in other words, the NID can facilitate profit-shifting and tax avoidance.

IKEA Service Centre NV provides the short-term loans which secure long-term intracompany loans made by its Dutch parent company (IKEA Capital BV) to IKEA Group subsidiaries in countries including Australia, the Netherlands, France, Norway, the US and China. The corresponding interest payments by these IKEA Group subsidiaries reduce their taxable income. The income that ultimately flows to IKEA Service Center NV from these interest payments faces almost no tax thanks to the NID.

The specific tax avoidance model for nominal interest deduction is shown in Fig. 4.

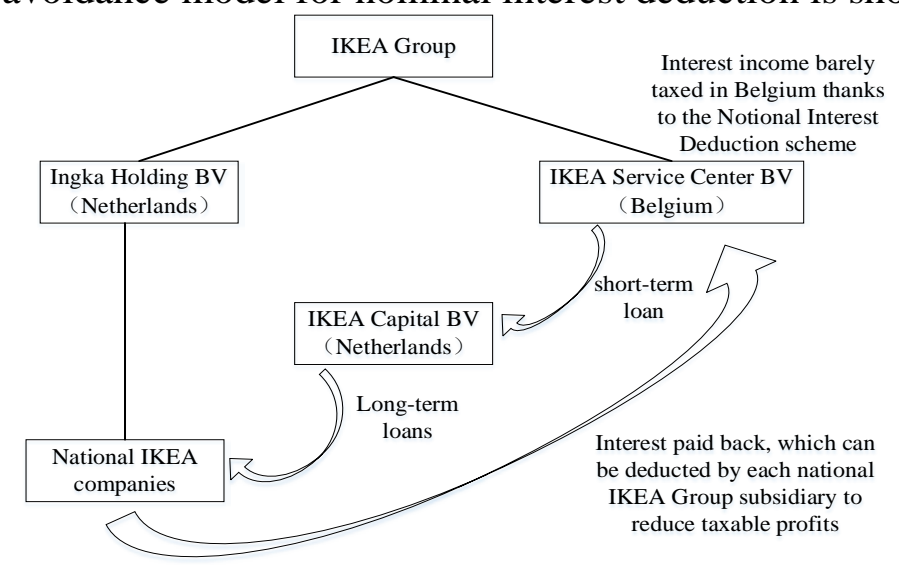

Fig. 4 The tax avoidance model of nominal interest deduction

\subsubsection{Effect-greatly reduced actual tax rate}

The IKEA Group has also benefitted from the coordination centre regime through its Belgian subsidiary, IKEA Service Centre NV, which serves as the internal treasury for the Group. From 2005 through 2009, while formally designated as a coordination centre, IKEA Service Centre NV paid just $0.04 \%$ in tax on $€ 1.96$ billion in profits - a savings of $€ 647$ million as compared with Belgium's statutory tax rate of 33\%.From 2010 through 2014, IKEA Service Centre NV (an IKEA Group subsidiary) claimed $€ 1.2$ billion in notional interest deductions and paid just $€ 37.5$ million in tax on net income of $€ 1.6$ billion. This equates to an effective tax rate of $2.4 \%-$ a savings of more than €488 million, as compared with Belgium’s statutory rate of 33.3\%.

\section{Inspiration from IKEA International Tax Planning}

\subsection{Revelations for Chinese enterprises in transnational operation}

Tax benefits are an important part of the overall interests of enterprises, the maximization of corporate tax benefits is also conducive to the realization of other goals such as expanding market share and increasing profits. Famous multinational corporations in the world, such as Google, Apple and IKEA, all take the maximization of tax benefits as one of their corporate goals. Legality is the first principle of tax planning for multinational companies. The management of multinational corporations in developed countries pay much more attention to tax planning than the management of large enterprises in China. They will set up a special tax department or organization in the company, and employ professional tax or legal talents for tax administration. Or they may hire a professional tax company to design a tax planning program. China's transnational enterprises are in the process of continuous growth should draw lessons from the beneficial experience of international, make up for the inadequacy of itself in the international tax planning, obtain many advantages in the fierce competition in the international market. 


\subsection{Concern about the environment changes and watch the tax planning risk}

The benefits and risks of international tax planning coexist. On the one hand, the international environment is increasingly complex. In 2015, the action plan for the tax base erosion and profit transfer (BEPS) project was released comprehensively, highlighting substantive business activities and demanding greater tax transparency and certainty. In 2016, the EU proposed a tax avoidance "package", calling on member states to take a tougher stance against aggressive tax planning by multinational companies. It can be seen that sovereign states and international organizations have increasingly strict requirements on tax planning of transnational corporations, and tax planning is becoming more and more difficult and risky. On the other hand, tax planning is a long-term process, and the expected results of tax planning are usually at some point in the future. If the policy environment changes unfavorably between the design of schemes and the expected results, it is likely to be unrewarding. This requires that the company in the tax planning scheme design, beware before effective means of tax law, closely tracking the policy environment change, the dynamic innovation, under the principle of legitimate design scheme that the tax benefit maximization.

\subsection{Insist on tax compliance and flexibly use tax planning methods}

Although the international tax planning is risky, the international tax planning methods are flexible and diverse. For example, the use of a country's special tax status and preferential tax policies to reduce the actual tax rate of taxable income. Transfer profits through tax havens to avoid domestic taxes. Reduce the group's overall taxable income by increasing the expense deduction. Avoid withholding tax by setting up financial companies. Profit distribution through cost sharing agreement. If the enterprise can in this company at the same time, the intensive analysis of the operating and taxation conditions to comply with its own tax law and international tax rules, flexible use of various tax planning methods, our country enterprise can in the increasingly severe international tax competition environment in a favorable position.

\section{References}

[1] Cohn, Michael. IKEA Accused of Tax Avoidance in Europe[J].Accounting today Com, 2016, $12: 1$

[2] Marc Auerbach. IKEA: Flat Pack Tax Avoidance. 2016.2. http://www.greensefa.eu/isl/ikea-flat-pack-tax-avoidance-15188.html.

[3] Morten Randeberg, Helge Selvik. A study of tax minimization strategies in multinational companies: with focus on The Coca-Cola Company and IKEA [J]. Biopolymers, 2014, 25(3): 469 487

[4] Peter Lundgren, IKEA entries at the WebJournal of International Taxation in Sweden, 2015, http://petersundgren. blogspot.com/search?q=ikea. 